\title{
THE MAKING OF CEREAL WITH SUBTITUTION OF SOYBEAN FLOUR (GLYCINE MAX L. MERR) AND PASTA FRUIT BIT (BETA VULGARIS L) AS NATURAL DYES
}

\author{
Hirwan Amanda ${ }^{1)}$, Irmayanti $^{1 *}$, Rita Sunartaty ${ }^{2)}$, \\ ${ }^{1}$ Program Studi Teknik Industri Pertanian, ${ }^{2}$ \\ ${ }^{2}$ Program Studi Teknologi Pangan, Fakultas Teknologi Pertanian, Universitas Serambi Mekkah Jl. \\ Unmuha, Batoh, Kec. Lueng Bata, Kota Banda Aceh, Aceh 23245 \\ *email: irmayanti@ serambimekkah.ac.id
}

\section{Article Info}

Article history:

Received

05/30/2021

Received in revised

07/30/2021

Accepted

$06 / 15 / 2021$

\begin{abstract}
Making cereals using wheat flour is a problem because the raw materials obtained are more expensive. In addition, wheat flour will have an adverse effect on some people who are sensitive to gluten. One of the best alternatives to wheat flour in the manufacture of cereals to produce low-gluten cereal products is tapioca flour. The purpose of this study is to determine the effect of adding soybean flour, beetroot paste and its interaction on physical and organoleptic characteristics of cereals. The results showed that the best treatment was found in the addition of $60 \%$ soybean flour and $85 \%$ beetroot paste (K3B3) which produced good quality serela with chemical properties, namely water content of $4.67 \%$, yield $63.00 \%$, water absorption 13,10\%, crispiness in milk 106 seconds, organoleptic test for taste 3.94 (like), aroma 4.10 (like), texture 2.67 (ordinary) and color 3.83 (like).
\end{abstract}

Keywords: cereals, soy bean, red bit, natural dye

\section{PEMBUATAN SEREAL DENGAN SUBTITUSI TEPUNG KEDELAI (GLYCINE MAX L. MERR) DAN PASTA BUAH BIT (BETA VULGARIS L) SEBAGAI PEWARNA ALAMI}

\begin{abstract}
Abstrak
Pembuatan sereal menggunakan tepung terigu menjadi suatu permasalahan dikarenakan bahan baku yang didapatkan menjadi lebih mahal. Selain itu tepung terigu akan menimbulkan efek buruk pada beberapa orang yang sensitif terhadap gluten. Salah satu alternatif terbaik pengganti tepung terigu dalam pembuatan sereal untuk menghasilkan produk sereal bergluten rendah adalah dengan tepung tapioka. Adapun tujuan dari penelitian ini adalah mengetahui pengaruh penambahan tepung kacang kedelai, pasta buah bit dan interaksinya terhadap karakteristik fisik dan organoleptik sereal. Hasil penelitian menunjukkan Perlakuan terbaik terdapat pada penambahan tepung kacang kedelai $60 \%$ dan pasta buah bit $85 \%$ (K3B3) yang menghasilkan serela mutu yang baik dengan sifat kimia yaitu kadar air 4,67\%, rendemen $63,00 \%$, daya serap air $13,10 \%$, kerenyahan dalam susu 106 detik, uji organoleptik rasa 3,94
\end{abstract}


(suka), aroma 4,10 (suka), tekstur 2,67 (biasa) dan warna 3,83 (suka).

Kata kunci: sereal, kedelai, buah bit, pewarna alami

\section{PENDAHULUAN}

Selama ini bahan pembuatan sereal menggunakan tepung terigu yang diimpor dari luar. Hal ini menjadi suatu permasalahan dikarenakan bahan baku yang didapatkan menjadi lebih mahal. Selain itu tepung terigu akan menimbulkan efek buruk pada beberapa orang yang sensitif terhadap gluten (gluten intolerance) yang ditandai dengan terjadinya radang mukosa usus halus sehingga mukosa tidak dapat berfungsi secara normal (Winarno, 2008).

Alternatif terbaik pengganti tepung terigu dalam pembuatan sereal untuk menghasilkan produk sereal bergluten rendah adalah dengan tepung tapioka. Tepung tapioka memiliki sumber protein yang rendah sebesar 0,5/100 gram sedangkan tepung terigu memiliki nilai protein 8,5/100 gram. Tapioka merupakan sumber karbohidrat yang cukup tinggi, berdasarkan data Departemen Kesehatan RI (2009). Karbohidrat tepung tapioka memiliki nilai 86,9 gram dari 100 gram. Sedangkan pada tepung terigu bernilai 77,3 gram. Dalam penelitian ini kebutuhan protein dapat diperoleh dari kacang kedelei yang ditambahkan dalam produk sereal. Protein pada kacang kedelai memiliki kandungan yang tinggi berkisar antara $36.00 \%$ (Astawan, 2009).

Pada penelitian sebelumnya yang dilakukan oleh Novia dkk (2014) tentang formulasi dan evaluasi sifat sensoris dan fisikokimia produk flakes komposit berbahan dasar tepung tapioka, tepung kacang merah (Phaseolus vulgaris L.) dan tepung konjac (Amorphophallus oncophillus)". Menghasilkan perkakuan terbaik yaitu dengan menggunakan tepung tapioka 50\%, tepung kacang merah $47 \%$ dan tepung konjac $3 \%$.

Penelitian yang dilakukan oleh Mila (2014) tentang pengaruh penambahan puree bit (Beta Vulgaris L) terhadap sifat organoleptik kerupuk. Hasil penelitian menunjukkan bahwa penambahan puree bit $75 \%$ berpengaruh nyata terhadap sifat organoleptik kerupuk bit yang meliputi warna, aroma, rasa dan kerenyahan, dibandingkan dengan penambahan puree $25 \%$ dan $50 \%$. Kerupuk bit penambahan puree $75 \%$ menghasilkan aroma, rasa dan kerenyahan terbaik dibandingkan dengan penambahan puree $20 \%$ dan $50 \%$.

Bit saat ini juga dimanfaatkan sebagai salah satu sumber zat pewarna alami. Umbi bit memiliki ciri spesifik bewarna merah. Walaupun bewarna merah umbi ini tidak memiliki pigmen merah (antosianin). Rata-rata bit mengandung pigmen betalain sebesar $1.000 \mathrm{mg} / 100 \mathrm{gr}$ berat kering atau $120 \mathrm{mg} / 100 \mathrm{gr}$ berat basah. Bit merupakan sumber potensial akan serat pangan serta berbagai vitamin dan mineral yang dapat digunakan sebagai sumber antioksidan yang potensial dan membantu mencegah infeksi. Bit juga mengandung karbohidrat, protein dan lemak yang berguna untuk kesehatan tubuh (Wirakusumah, 2007).

Keterbaharuan dalam penelitian yang akan saya lakukan dalam pembuatan sereal adalah dengan menggunakan tepung tapioka sebesar $100 \mathrm{gr}$, tepung kacang kedelai sebesar $60 \%, 50 \%, 40 \%$, serta penambahan pasta buah bit sebesar $65 \%$, $75 \%, 85 \%$. 


\section{METODE PENELITIAN}

\section{Waktu dan Tempat Penelitian}

Penelitian ini telah dilaksanakan pada bulan Mai sampai dengan Juni 2019 di Laboratorium Pengolahan Hasil Pertanian, Laboratorium Analisis Hasil Pertanian dan Laboratorium Organoleptik Fakultas Teknologi Pertanian, Universitas Serambi Mekkah, Banda Aceh.

\section{Alat dan Bahan}

Bahan yang digunakan pada penelitian ini adalah tepung kacang kedelai, tepung tapioka, susu skim, garam, vanili, gula, margarin, telur, air dan bahan yang digunakan dalam analisis adalah susu cair. Alat yang digunakan pada penelitian ini adalah panci, roller, timbangan, baskom plastik, sendok, alat pengering, loyang, kompor, timbangan dan alat yang digunakan untuk analisis adalah timbangan analitik, desikator, cawan, oven, mistar kurva derajat putih, gelas ukur $100 \mathrm{ml}$.

\section{Rancangan Penelitian}

Penelitian ini dilakukan menggunakan Rancangan Acak Lengka(RAL)faktorial. Terdiri dari dua faktor yaitu :

1. Faktor I Penambahan tepung kacang kedelai (K) terdiri dari 3 level yaitu : $\mathrm{K} 1$ $=40 \%, \mathrm{~K}_{2}=50 \%, \mathrm{~K}_{3}=60 \%$

2. Faktor II Penambahan pasta buah bit (B) terdiri dari 3 level yaitu : $\mathrm{B} 1=65$ $\%, \mathrm{~B}_{2}=75 \%, \mathrm{~B}_{3}=85 \%$

Kombinasi perlakuan adalah $3 \times 3$ level dengan 2 kali pengulangan sehingga diperoleh 18 satuan percobaan. Susunan kombinasi perlakuan dapat dilihat pada Tabel 1.
Tabel 1. Susunan kombinasi perlakuan

Penambahan pasta buah bit

\begin{tabular}{cccc} 
Penambahan & \multicolumn{3}{c}{$(\mathrm{B})$} \\
tepung & $\mathrm{B} 1=65$ & $\mathrm{~B} 2=75$ & $\mathrm{~B} 2=$ \\
kedelai(K) & $\%$ & $\%$ & $85 \%$ \\
\hline $\mathrm{K} 1=40 \%$ & $\mathrm{~K} 1 \mathrm{~B} 1$ & $\mathrm{~K} 1 \mathrm{~B} 2$ & $\mathrm{~K} 1 \mathrm{~B} 3$ \\
$\mathrm{~K} 2=50 \%$ & $\mathrm{~K} 2 \mathrm{~B} 1$ & $\mathrm{~K} 2 \mathrm{~B} 2$ & $\mathrm{~K} 2 \mathrm{~B} 3$ \\
$\mathrm{~K} 3=60 \%$ & $\mathrm{~K} 3 \mathrm{~B} 1$ & $\mathrm{~K} 3 \mathrm{~B} 2$ & $\mathrm{~K} 3 \mathrm{~B} 3$
\end{tabular}

\section{Pembuatan Tepung kedelai (Badan}

Standar Nasional, 2000)

Kacang kedelai disortasi.

Kemudian dicuci dan ditiriskan selama \pm 15 menit. Lalu dikeringkan dengan suhu \pm $60^{\circ} \mathrm{C}$ selama 12 jam. Selanjutnya dihancurkan menggunakan blender selama 10 menit, dan diayak dengan ayakan 80 mesh.

\section{Pembuatan pasta buah bit (Steed dan Truong, 2008)}

Buah bit disortasi dan dikupas. Kemudian dicuci dan dipotong-potong bentuk dadu dengan ketebalan $\pm 1 \mathrm{~cm}$. Kemudian dikukus selama 15 menit. Lalu setelah dingin dihaluskan menggunakan blender.

\section{Pembuatan Sereal (Novia dkk, 2014)}

Dicairkan mentega 4 gram hingga mencair, kemudian didinginkan. Lalu dikocok telur 20 gram hingga tercampur. Kemudian masukkan tepung kacang kedelai $(40 \%, 50 \%, 60 \%)$, pasta buah bit $(65 \%, 75 \%, 85 \%)$, susu skim 10 gram, vanili 1 gram, diaduk jadi satu, lalu tambahkan kocokan telur dan mentega cair. Adonan diaduk hingga merata. Kemudian cetak adonan pada cetakan. Kemudian di oven selama 25 menit, dengan suhu $\pm 140{ }^{\circ} \mathrm{C}$. Setelah dioven 
dikemas dan dianalisa kadar air dan uji organoleptik (rasa, aroma, warna dan tekstur).

\section{METODE ANALISA}

\section{Analisa Kadar Air (Sudarmadji dkk, 1997).}

Cawan kosong dikeringkan dalam oven selama 15 menit dan dinginkan dalam desikator, kemudian ditimbang kurang lebih 5 gram sampel yang sudah dihomogenkan dalam cawan. Diangkat tutup cawan dan tempatkan cawan beserta isi dan tutupnya didalam oven selama 6 jam. Hindarkan kontak antara cawan dengan dinding oven. Dipindahkan cawan ke desikator, tutup dengan penutup cawan, lalu dinginkan. Ditimbang kembali bahan. Dikeringkan kembali dengan oven sampai diperoleh berat yang tetap

\section{Rendemen (Buana, 2012)}

Rendemen adalah sebuah nilai yang menunjukkan perbandingan hasil (output) dan bahan baku (input) dan dilihat dari sudut pandang apapun. Pada dasarnya rendemen dapat diartikan sebagai efisiensi proses dan kualitas hasil dan tentunya banyak faktor yang mempengaruhi. Adapun rumus rendemen sebagai berikut :

Rendemen $(\%)=\frac{\text { Berat akhir }}{\text { Berat awal }} \times 100 \%$

\section{Daya Serap Air (AOAC, 2000 dalam Lase dkk, 2013)}

Sampel sebanyak 5 gram (sereal) dimasukkan kedalam air mendidih 100 mL. Lalu ditutup dan dimasak sampai sereal tergelatinisasi sempurna selama 5 menit. Sereal yang telah masak sempurna ditimbang. Penyerapan air diukur berdasarkan perubahan sebelum dan sesudah pemasakan
Daya serap air $(\%)=$

Berat sampel masak $(g) \times 100 \%$

Berat sampel mentah $(g)$

\section{Ketahanan Kerenyahan dalam Susu}

Pengujian ini dilakukan untuk menentukan ketahanan sereal saat disajikan dengan susu cair dalam keadaan masih cukup renyah saat dikonsumsi. Penentuan ketahanan dilakukan dengan cara menuangkan 1,5 gr sereal kedalam mangkok kemudian dituangkan susu cair dengan suhu susu $29^{\circ} \mathrm{C}$ sebanyak $70 \mathrm{~mL}$. Waktu sereal untuk dapat bertahan mengapung di permukaan hingga tekstur tidak cukup renyah dihitung sebagai waktu ketahanan dalam susu.

\section{PEMBAHASAN}

Dari data hasil analisis diperoleh kadar air berkisar antara 4,67\% - 4,87\% dengan rata-rata $4,76 \%$. Kadar air tertinggi diperoleh pada penambahan tepung kacang kedelai $40 \%$ dan penambahan pasta buah bit $75 \%$ (K1B2) sebesar 4,85\%, sedangkan nilai rata-rata kadar air terendah diperoleh pada penambahan tepung kacang kedelai $60 \%$ dan penambahan pasta buah bit $65 \%$ (K3B1) sebesar $4,67 \%$. Data rata - rata hasil analisa kadar air dapat dilihat pada Tabel 2.

Tabel 2. Data rata rata analisa kadar air

\begin{tabular}{lllll}
$\frac{2}{2} \begin{array}{c}\text { sereal } \\
\text { Penambahan } \\
\text { tepung }\end{array}$ & & \multicolumn{3}{l}{ Penambahan pasta buah bit (B) } \\
\cline { 5 - 5 } kacang & & B1= & B2= & B3= \\
kedelai (K) & & $65 \%$ & $75 \%$ & $85 \%$ \\
\hline K1 $=40 \%$ & & 4,86 & 4,87 & 4,85 \\
K2 $=50 \%$ & & 4,77 & 4,76 & 4,77 \\
K3 $=60 \%$ & & 4,67 & 4,68 & 4,67 \\
\hline
\end{tabular}

Hasil analisis sidik ragam (Lampiran 4c) menunjukkan bahwa 
penambahan tepung kedelai berpengaruh sangat nyata $(\mathrm{P} \leq 0,01) \quad$ sedangkan penambahan pasta buah bit serta interaksi antara kedua perlakuan berpengaruh tidak nyata $(\mathrm{P}>0,05)$ terhadap kadar air pada sereal. Pengaruh penambahan tepung kedelai terhadap kadar air sereal yang dihasilkan dapat dilihat pada Gambar 1.

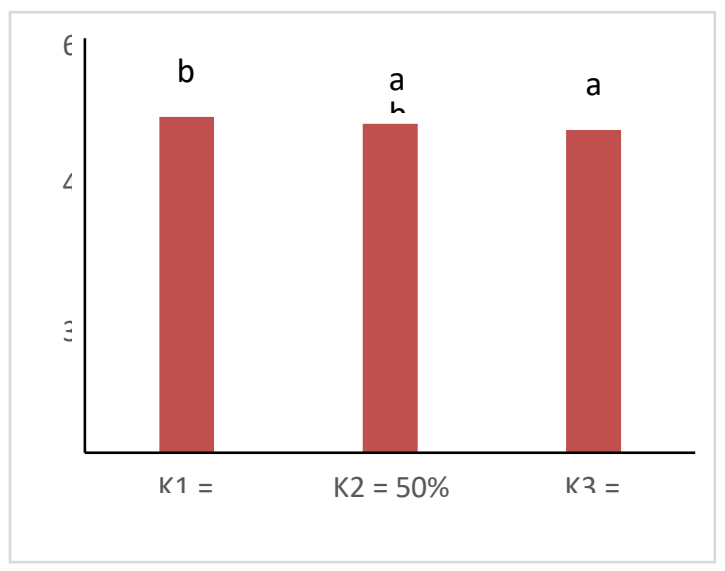

Gambar 1. Pengaruh penambahan tepung kacang kedelai $(\mathrm{K})$ terhadap kadar air sereal $(\mathrm{BNT} 0,01=0,11 \%$ dan KK $=1,21 \%$ ). Notasi yang sama menunjukkan perbedaan yang tidak nyata.

Dari Gambar 1 dapat dilihat bahwa semakin tinggi penambahan tepung kedelai maka kadar air yang dihasilkan pada sereal semakin rendah. Hal ini disebabkan tepung kedelai memiliki kadar pati yang besar yaitu $13,27 \%$. Pati akan mengabsorbsi air selama proses pemanggangan. Akibatnya, air yang berada dalam pori-pori sereal akan semakin banyak sehingga air yang teruapkan akan semakin banyak selama proses gravimetri (Judi dkk, 2009). Sehingga semakin banyak penambahan tepung kacang kedelai, maka kadar air sereal semakin kecil. Menurut Mc Williams (2001) air akan terikat oleh pati ketika mengalami gelatinisasi dan akan berkurang pada saat pemanggangan, proses ini menurunkan kadar air dan mengubah adonan menjadi renyah pada saat pemanggangan.

Dari analisis kadar air sereal tidak memenuhi syarat SNI sebagai bahan makanan pada semua perlakuan. SNI kadar air sereal maksimal 3\%, sedangkan persentase parameter kadar air yang dihasilkan memiliki kadar air rata - rata 4,76\%. Hal ini disebabkan karena kandungan air yang tinggi pada tepung kedelai 9,00\% (Winarsi, 2010), sehingga kadar air yang dihasilkan pada sereal tidak memenuhi SNI.

\section{Rendemen}

Rendemen adalah perbandingan jumlah (kuantitas) bahan yang dihasilkan dari proses pengolahan. Rendemen menggunakan satuan persen (\%). Semakin tinggi nilai rendemen yang dihasilkan menandakan nilai bahan yang dihasilkan semakin banyak. (Fahmi, 2016).

Dari data hasil analisis diperoleh rendemen berkisar antara 53,15\% $64,35 \%$ dengan rata-rata $58,44 \%$. Rendemen tertinggi diperoleh pada penambahan tepung kacang kedelai $40 \%$ dan penambahan pasta buah bit $65 \%$ (K1B1) sebesar $64,35 \%$, sedangkan nilai rata-rata rendemen terendah diperoleh pada penambahan tepung kacang kedelai $60 \%$ dan penambahan pasta buah bit $75 \%$ (K3B2) sebesar 53,15\%. Data rata - rata hasil analisa rendemen dapat dilihat pada Tabel 3. 
Tabel 3. Data rata rata analisa rendemen sereal

\begin{tabular}{llll}
\hline $\begin{array}{l}\text { Penambahan } \\
\text { tepung kacang }\end{array}$ & \multicolumn{3}{l}{ Penambahan pasta buah bit (B) } \\
\cline { 2 - 4 } kedelai (K) & $\begin{array}{l}\mathrm{B} 1= \\
65 \%\end{array}$ & $\mathrm{~B} 2=75 \%$ & $\mathrm{~B} 3=85 \%$ \\
& 64,15 & 56,15 & 55,85 \\
$\mathrm{~K} 1=$ & 54,85 & 59,75 & 61,65 \\
$40 \%$ & 51,30 & 63,05 & 63,00 \\
$\mathrm{~K} 2=50 \%$ & 57,85 & \\
$\mathrm{~K} 3=60 \%$ & 6
\end{tabular}

Hasil analisis sidik ragam (Lampiran 5c) menunjukkan bahwa penambahan tepung kacang kedelai berpngaruh sangat nyata $(\mathrm{P} \leq 0,01)$ dan penambahan pasta buah bit berpengaruh nyata $(P \leq 0,05)$ sedangkan interaksi antara kedua perlakuan berpengaruh tidak nyata ( $>0$ 0,05) terhadap rendemen pada sereal. Pengaruh penambahan tepung kedelai dan penambahan pasta buah bit terhadap rendemen sereal yang dihasilkan dapat dilihat pada Gambar 2 dan Gambar 3.

Dari Gambar 2 dapat dilihat bahwa semakin tinggi penambahan tepung kacang kedelai maka rendemen sereal yang dihasilkan meningkat. Hal ini disebabkan karena kandungan air pada tepung kacang kedelai 9,00\% (Winarsi, 2010) yang mempengaruhi bobot bahan. Hal ini juga terjadi karena komponen bahan yang terdapat dalam adonan tidak mengakibatkan kehilangan berat bahan secara signifikan selama proses pemanggangan berlangsung. Kehilangan berat bahan biasanya terjadi ketika ada komponen bahan yang ikut menguap saat proses pemasakan atau adanya bahan yang tertinggal pada material bahan yang digunakan. Kemudian kandungan pati pada tepung kedelai $(13,27 \%)$ karena sifat dari molekul pati yang hidrofilik sehingga semakin tinggi tepung kedelai yang ditambahkan semakin tinggi pula kadar air maka rendemen yang dihasilkan semakin tinggi. Sri dkk (2016) telah melakukan penelitian serela pisang kepok dengan penambahan tepung cassava $30 \%$ menghasilkan rendemen $62,63 \%$.

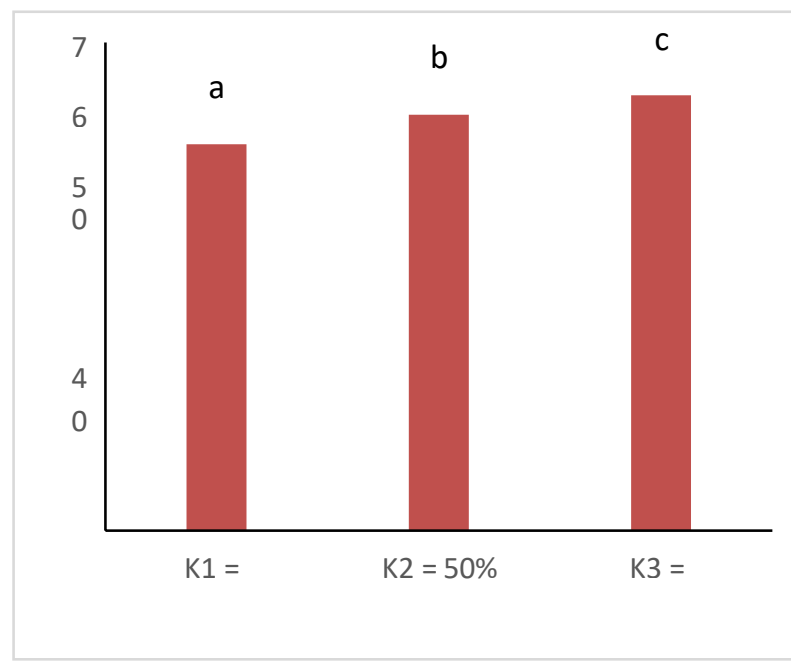

Gambar 2 Pengaruh penambahan tepung kacang kedelai (K) terhadap rendemen sereal yang dihasilkan $($ BNT $0,01=2,63 \%$ dan $\mathrm{KK}=$ 2,37\%). Notasi yang sama menunjukkan perbedaan yang tidak nyata.

Dari Gambar 2 dapat dilihat bahwa semakin tinggi penambahan pasta buah bit maka rendemen sereal yang dihasilkan meningkat. Hal ini disebabkan karena kandungan air buah bit 87,58\% (USDA, 2014) berpengaruh pada rendemen karena air dalam bahan pangan merupakan komponen utama yang mempengaruhi bobot bahan. Kemudian kandungan pati yang tinggi $(35,81 \%)$ sehingga mudah mengikat air. Semakin banyak air yang terikat maka berat rendemen akan semakin tinggi. Sri dkk (2016) telah melakukan penelitian sereal pisang kepok dengan penambahan tepung 
cassava $30 \%$ menghasilkan rendemen $62,63 \%$.

Pemanggangan merupakan proses terakhir dari tahapan pembuatan sereal. Pemanggangan menghasilkan rendemen rata-rata $58.44 \%$. Hal ini diduga karena pemanggangan menggunakan panas yang berfungsi untuk mengeluarkan kandungan air dari bahan pangan. Oleh karena itu, produk yang dihasilkan renyah dengan kadar air yang rendah. Kadar air maksimal untuk produk sereal berdasarkan SNI maksimum 3\% (BSN, 1996).

\section{Daya Serap Air}

Daya serap air menunjukkan kemampuan sereal untuk menyerap cairan setelah direndam atau diseduh, besarnya daya serap air menunjukkan kualitas sereal ketika dikonsumsi. Analisa daya serap air dilakukan untuk mengetahui besarnya kemampuan menyerap air dalam jumlah besar dan relatif singkat setelah dilakukan proses perendaman dengan air.

Dari data hasil analisis diperoleh daya serap air berkisar antara 10,80\% $13,90 \%$ dengan rata-rata $12,49 \%$. Daya serap air tertinggi diperoleh pada penambahan tepung kacang kedelai $40 \%$ dan penambahan pasta buah bit $85 \%$ (K1B3) sebesar 13,90\%, sedangkan nilai rata-rata daya serap air terendah diperoleh pada penambahan tepung kacang kedelai $50 \%$ dan penambahan pasta buah bit $75 \%$ (K2B2) sebesar 10,80\%. Data rata - rata hasil analisa daya serap air dapat dilihat pada Tabel 4.
Tabel 4 Data rata rata analisa daya serap air sereal

\begin{tabular}{cccc}
\hline $\begin{array}{c}\text { Penambahan } \\
\text { tepung kacang } \\
\text { kedelai (K) }\end{array}$ & \multicolumn{3}{c}{$\begin{array}{c}\text { Penambahan pasta buah } \\
\text { bit (B) }\end{array}$} \\
\cline { 2 - 4 } & $\begin{array}{c}\mathrm{B} 1= \\
65 \%\end{array}$ & $\mathrm{~B} 2=$ & $\mathrm{B} 3=$ \\
$\mathrm{K} 1=45 \%$ & $85 \%$ \\
$\mathrm{~K} 2=50 \%$ & 13,40 & 12,45 & 13,90 \\
$\mathrm{~K} 3=60 \%$ & 12,90 & 10,80 & 11,95 \\
\hline
\end{tabular}

Hasil analisis sidik ragam menunjukkan bahwa penambahan tepung kacang kedelai berpengaruh nyata $(\mathrm{P} \leq 0,05)$ dan penambahan pasta buah bit berpengaruh tidak nyata $(\mathrm{P}>0,05)$ sedangkan interaksi antara kedua perlakuan berpengaruh sangat nyata $(\mathrm{P} \leq 0,01)$ terhadap uji daya serap air pada sereal. Pengaruh interaksi antara penambahan tepung kacang kedelai dan pasta buah bit terhadap daya serap air sereal yang dihasilkan dapat dilihat pada Gambar 4 bahwa semakin tinggi penambahan tepung kacang kedelai dan pasta buah bit maka daya serap air yang dihasilkan cenderung meningkat. Pada perlakuan penambahan tepung kacang kedelai 50\% ada penurunan daya serap air.

Tepung kacang kedelai dan pasta buah bit memiliki kandungan pati dan proteinnya dimana diketahui bahwa tepung kedelai mengandung protein sebesar 40,0 $\%$ sedangkan buah bit $1,6 \%$ protein (Aminah dan Hersoelistyorini, 2012). Hubungan antara kandungan pati dan protein terhadap daya serap air sudah dinyatakan oleh Apriliyanti (2010) bahwa penambahan tepung kacang kedelai yang merupakan sumber protein akan menyebabkan daya serap air meningkat karena hampir semua protein mengandung jumlah polar sepanjang kerangka 
peptidanya dan membuatnya bersifat hidrofilik. Fardiaz dkk (1992) bahwa penyerapan air tergantung pada ketersediaan grup hidrofilik.

Pada penambahan pasta buah bit $85 \%$ daya serap air cendrung meningkat. Hal ini disebabkan karean buah bit memiliki serat 2,5\%, Menurut Tala (2009) serat pangan memiliki daya serap air yang tinggi, karena ukuran polimernya besar, strukturnya kompleks dan banyak mengandung gugus hidroksil sehingga mampu menyerap air dalam jumlah yang besar. Semakin tinggi kadar serat yang dihasilkan semakin banyak juga air yang terserap menyebabkan adonan sereal menjadi lunak sehingga kemampuan membentuk rongga-rongga udara yang dapat memerangkap udara menjadi rendah.

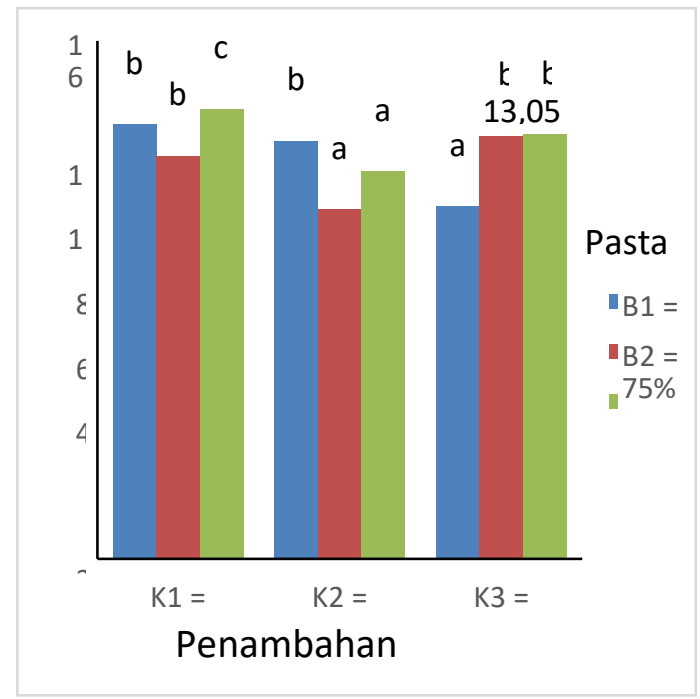

Gambar 3. Pengaruh interaksi antara penambahan tepung kacang kedelai dan pasta buah bit terhadap daya serap air sereal yang dihasilkan $(\mathrm{BNT} 0,01=$ $1,15 \%$ dan $\mathrm{KK}=4,90 \%$ ). Notasi yang sama menunjukkan perbedaan yang tidak nyata.

\section{Kerenyahan dalam Susu}

Kerenyahan dalam susu ini dilakukan untuk menentukan ketahanan sereal saat disajikan dengan susu cair dalam keadaan masih cukup renyah saat dikonsumsi. Untuk produk jenis sereal yang disajikan dengan susu, konsumen cenderung lebih menyukai produk yang terehidrasi lebih lama di dalam media saji karena kerenyahan produk dapat dinikmati lebih lama (Mannie, 1999).

Dari data hasil analisis diperoleh kerenyahan dalam susu berkisar antara 106 detik - 147 detik dengan rata-rata 123 detik. Kerenyahan dalam susu tertinggi diperoleh pada penambahan tepung kacang kedelai $60 \%$ dan penambahan pasta buah bit $85 \%$ (K3B3) sebesar 147 detik, sedangkan nilai rata-rata kerenyahan dalam susu terendah diperoleh pada penambahan tepung kacang kedelai $40 \%$ dan penambahan pasta buah bit 65\% (K1B1) sebesar 106 detik. Data rata - rata hasil analisa kerenyahan dalam susu dapat dilihat pada Tabel 5.

Tabel 5. Data rata rata analisa kerenyahan dalam susu sereal

\begin{tabular}{lcll}
\hline $\begin{array}{l}\text { Penambah } \\
\text { an tepung } \\
\text { kacang }\end{array}$ & \multicolumn{3}{c}{$\begin{array}{l}\text { Penambahan pasta } \\
\text { buah bit (B) }\end{array}$} \\
\cline { 2 - 4 } kedelai (K) & $\mathrm{B} 1=65 \%$ & $\mathrm{~B} 2=75 \%$ & $\begin{array}{l}\mathrm{B} 3=85 \\
\%\end{array}$ \\
\hline $\mathrm{K}_{1}=40 \%$ & 147 & 137 & 132 \\
$\mathrm{~K}_{2}=50 \%$ & 126 & 128 & 119 \\
$\mathrm{~K}_{3}=60 \%$ & 107 & 105 & 107 \\
\hline
\end{tabular}

Hasil analisis sidik ragam menunjukkan bahwa penambahan tepung kacang kedelai berpengaruh sangat nyata $(\mathrm{P} \leq 0,01)$ dan penambahan pasta buah bit berpengaruh nyata $(\mathrm{P} \leq 0,05)$ sedangkan interaksi antara kedua perlakuan berpengaruh tidak nyata $(\mathrm{P}>0,05)$ terhadap uji kerenyahan dalam 
susu pada sereal. Pengaruh penambahan tepung kacang kedelai dan penambahan pasta buah bit terhadap kerenyahan dalam susu yang dihasilkan dapat dilihat pada Gambar 4 dan Gambar 5.

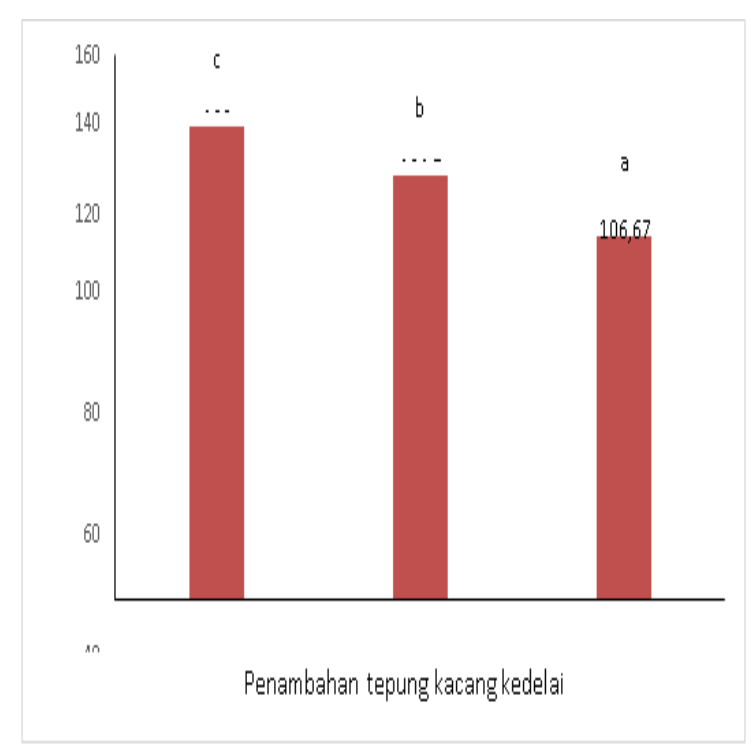

Gambar 4. Pengaruh penambahan tepung kacang kedelai (K) terhadap kerenyahan dalam susu yang dihasilkan (BNT 0,01 : 7,20\% dan $\mathrm{KK}=3,82 \%)$. Notasi yang sama menunjukkan perbedaan yang tidak nyata.

Dari Gambar 4 dapat dilihat bahwa semakin tinggi penambahan kacang kedelai maka kerenyahan sereal dalam susu semakin rendah. Hal ini disebabkan oleh kandungan pati $(13,27 \%)$ dan serat $(3,5 \%)$ yang terkandung dalam tepung kacang kedelai. Pati berperan dalam pembentukan stuktur serela. Pati akan berikatan dengan air, dan dengan adanya perlakuan suhu tinggi pati akan tergelatinisasi sehingga akan terbentuk rongga-rongga pada struktur produk. Demikian halnya dengan serat kasar, yang mudah menyerap air. Semakin banyak rongga dalam tekstur sereal maka semakin mudah sereal menyerap air dan kerenyahan sereal dalam susu tidak bertahan lama (Permana dan Putri, 2015).
Sifat dari serat dan pati terhadap air berbeda, dimana pati lebih tahan terhadap air, sedangkan serat bersifat menyerap air. Sehingga sereal yang dibuat dengan konsentrasi tepung kacang kedelai yang tinggi lebih mudah menyerap air sehingga lebih cepat hancur dalam susu.

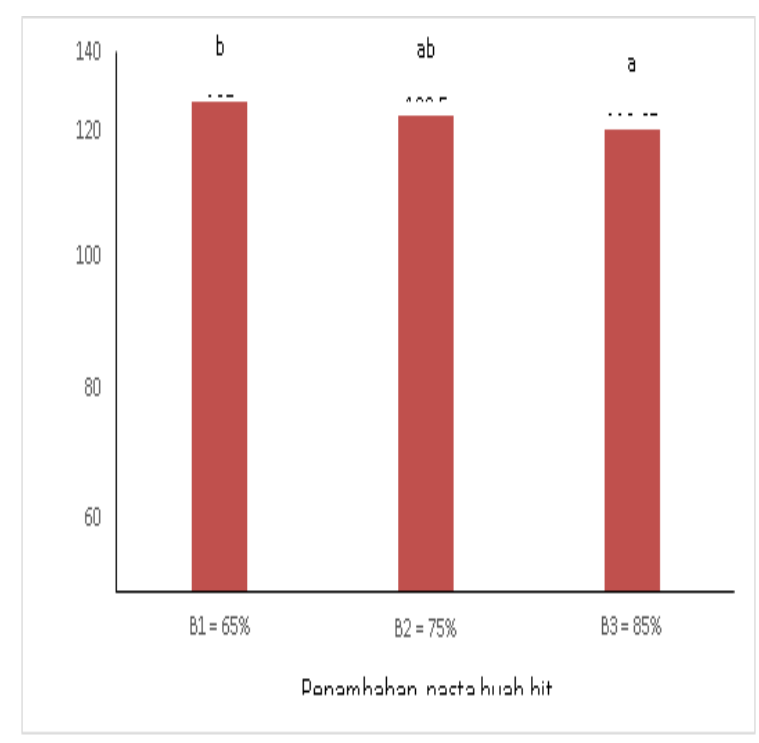

Gambar 5. Pengaruh penambahan pasta buah bit (B) terhadap kerenyahan dalam susu yang dihasilkan (BNT $0.05: 5,20 \%$ dan $\mathrm{KK}=3.82 \%$ ). Notasi yang sama menunjukkan perbedaan yang tidak nyata.

Dari Gambar 5 dapat dilihat bahwa semakin tinggi penambahan pasta buah bit maka kerenyahan sereal dalam susu semakin rendah. Hal ini disebabkan oleh serat $(2,5 \%)$ yang terkandung pada buah bit. Serat kasar mudah menyerap air. Semakin banyak rongga dalam tekstur sereal maka semakin mudah sereal menyerap air dan kerenyahan sereal dalam susu tidak bertahan lama. Menurut Tala (2009) serat pangan memiliki daya serap air yang tinggi, karena ukuran polimernya besar, strukturnya kompleks dan banyak mengandung gugus hidroksil sehingga mampu menyerap air dalam jumlah yang besar. Semakin tinggi kadar serat yang 
dihasilkan semakin banyak juga air yang terserap menyebabkan adonan sereal menjadi lunak sehingga kemampuan membentuk rongga-rongga udara yang dapat memerangkap udara menjadi rendah.

\section{KESIMPULAN}

Penambahan tepung kacang kedelai (K) berpengaruh sangat nyata terhadap kadar air, rendemen, kerenyahan dalam susu dan berpengaruh nyata terhadap daya serap air serta tidak berpengaruh nyata terhadap uji organoleptik uji organoeptik (rasa, aroma, warna dan tekstur) sereal. Penambahan pasta buah bit (B) berpengaruh nyata terhadap rendemen, kerenyahan dalam susu dan berpengaruh tidak nyata terhadap daya serap air, kadar air uji organoleptik (rasa, aroma, warna dan tekstur) sereal. Interaksi antara subtitusi penambahan tepung kacang kedelai dan penambahan pasta buah bit berpengaruh nyata terhadap daya serap air dan tidak berpengaruh nyata terhadap kadar air, rendemen, kerenyahan dalam susu dan uji organoeptik (rasa, aroma, warna dan tekstur) sereal. Perlakuan terbaik terdapat pada penambahan tepung kacang kedelai $60 \%$ dan pasta buah bit $85 \%$ (K3B3) yang menghasilkan serela mutu yang baik dengan sifat kimia yaitu kadar air 4,67\%, rendemen $63,00 \%$, daya serap air $13,10 \%$, kerenyahan dalam susu 106 detik, uji organoleptik rasa 3,94 (suka), aroma 4,10 (suka), tekstur 2,67 (biasa) dan warna 3,83 (suka).

\section{DAFTAR RUJUKAN}

Alexander K.E., Ventura E.E., SpruijtMetz D., Weigensberg M.J., \& Davis J.N. 2009. Association of breakfast skipping with visceral fat and insulin indices in overweight latino youth.
Nature publishing group. Journal of the American Dietetic Association, 127, 15281533.

Alexander, W.R. Hypertension and the Pathogenesis of Atherosclerosis, Oxidative Stress and the Medication of Arterial Inflammatory Response : A New Perspective, Hypertension : 1995. $25: 15$ - 61. Avaible from : http://www.hyper.ahajournals.org.

Anonim. 2002. Standar Mutu Pakan Ternak. Badan Standarisasi Indonesia. Jakarta.

Astawan, Made. 2008. Olahan Sehat Dengan Buah. Jakarta: Dian Rakyat. Astawan, Made. 2009. Sehat dengan Hidangan Kacang dan Bijibijian. Jakarta: Penebar Swadaya

BA, YB Suhardjito. 2006. Pastry dalam Perhotelan. Yogyakarta: CV. Andi. Offset.

Badan Standardisasi Nasional. 2000. Syarat Mutu Sereal (SNI 01-42701996). Badan Standardisasi Nasional. Jakarta.

Badan Standarisasi Nasional 2000. Standar Nasional Indonesia (SNI) Standart Mutu Tepung Terigu (SNI 01-3751-2000/Rev). Jakarta: Departemen Perindustrian.

Barrington GM, Allen AJ, Parish SM, Tibary A. 2006. Biosecurity and biocontainment in alpaca operations. J Small Ruminant Res 6:217-225.

Departemen Kesehatan R.I. 2005. Kandungan Kimia Buah Bit. Jakarta: Depkes RI

Departemen Kesehatan. 2009. Pedoman Praktis Pemantauan Gizi.. Jakarta: Depkes

Drake, D.L., S.E. Gebhardt, and R.H. Matthews. (1989). Composition of Foods: Cereal Grains and Pasta. 
United States Department of Agriculture.

Johnson, L. A. 2008. Corn: Production, Processing and atilitation. Di dalam Lorenzo KJ, Kulp K, editor. Handboojk of Cereal Science and Technology. New York: Marcel Dekker Inc.

K.A. Wesnes. C. Pincock, D. Richardson, G Helm, Shails. 2003. Breakfast Reduces Declines in Attention and Memory Over The Morning in School Children. Missouriwestern University. Citied 26 September

Kelly ,H.W.,Sorkness, C.A., 2005, Asthma dalam Dipiro, J.T., Talbert, R.L., Yee, G.C., Matzke, G.R., Wells, B.J. dan Posey, L.M.,Pharmacotherapy A Pathophysiologic Approach, Sixth Edition, 517, The McGraw-Hill Companies, USA.

Mateo-Aparicio,I., Cuenca, A.R., Villanueva-Suarez, M.J., \& Zapata-Revilla,

M.A. 2008. Soybean, a Promising Health Source. J. Nutr. Hosp. 2008;23(4) : 305-312

Melisa Winda Br. Ginting, Evawany, Jumirah, 2013. Pengaruh penambahan tepung dan hasil parutan buah bit merah dalam pembuatan biskuit terhadap kandungan gizi. Fakultas Kesehatan Masyarakat. USU.

Mila Lestari, W. 2014. Pengaruh penambahan puree Bit (Beta Vulgaris L) terhadap sifat organoleptik kerupuk. Fakultas Teknik Universitas Surabaya.

Novia Rakhmawati, Bambang Sigit Amanto, Danar Praseptiangga. 2014. Formulasi dan evaluasi sifat sensoris dan fisikokimia produk flakes komposit berbahan dasar tepung tapioka, tepung kacang merah (phaseolus vulgaris L.) dan tepung konjac (amorphophallus oncophillus). UNS.

Nurjanah, E. 2000. Analisis Karakteristik Konsumen dan Pola Konsumsi Sereal Sarapan [Skripsi], Institute Pertanian Bogor.

K Nanang. 2008. Alternatif Sarapan Pagi dan Snack Sehat yang Praktis dan Kaya Protein Nabati. Penebar Swadaya. Jakarta.

Radley, J.A. 1976. Starch Production Technology. London: Applied Science Publ.

Rimbawan \& A. Siagian. 2000. Indeks Glikemik Pangan buah Bit, Cara Mudah Memilih Pangan yang Menyehatkan. Jakarta: Penebar Swadaya

Rubatzky,V.E dan Yamaguchi. 2006. (Sayuran Dunia, Prinsip, Produksi, dan Gizi, alih bahasa Catur Herison).ITB, Bandung

Santiago, E.C. and E.M. Yahlia. 2008. Identification and Quantification of Betalains from the Fruits of 10 Mexian Prickly Pear Cultivars by High- Performance Liquid Chromatography and Electrospray Ionization Mass Spectrometry. J. Agric. Food Chem.

Setiawan, A.I., 2005. Umbi Bit Budidaya Secara Komersial. Penebar Swadaya, Jakarta.

Siti Hamidah (2010). Patiseri. Yogyakarta: FPTK IKIP.

Soekarto. 2007. Penilaian Organoleptik Untuk Industri Pangan dan Hasil Pertanian. Jakarta : Bharat Aksara.

Supriyadi, D. 2012. Study on Effects of 
Amylose-Amylopectin Ratio and Water Content to Crispiness and Hardness of Fried Product Model. Department of Food Science and Technology.Faculty of Agricultural Engineering and Technology.IPB. Bogor.

Splittstoesser, W. E., 2002. Vegetable Growing Handbook. Van Nostrand Reinhold Company, New York.

Steed, L.E. \& Truong, V.D. 2008. Anthocyanin Content, Antioxidant Activity, and Selected Physical Properties of Flowable Purple Fleshed Sweet Potato Purees. Journal of Food Science, 73(5)

Sudarmadji S, dkk. 1997. Prosedur Analisa untuk Bahan Makanan dan Pertanian. Liberty. Yogyakarta

Sunarjono, H. 2004. Bertanam Umbi Bit. Penebar Swadaya. Jakarta. Suprapto, H. 1993. Bertanam Kedelai. Penebar Swadaya. Bogor.

Tribelhorn, R. E. 1991. "Breakfast Cereals", Handbook of Cereal Science and Technology. Marcel Dekker, Inc. USA.

Winarno, F.G. 2008. Kimia Pangan dan Gizi: Edisi Terbaru. Jakarta

Winarno. 2002. Pewarna alami bahan makanan. Jakarta. Swadaya.

Winarsi, Heri. 2010. Protein Kedelai dan Kecambah Manfaatnya bagi Kesehatan. Yogyakarta: Kanisius.

Wirakusumah (2007). Jus Buah dan Sayuran. Jakarta : Swadaya

Wirakusumah, Emma S.2005. Menikmati Telur- Bergizi, Lezat dan Ekonomi. Jakarta: Gramedia. 